\title{
Translation and Validation of Breastfeeding Self-Efficacy Scale- Short Form (BSES-SF) into Indonesian: a Pilot Study
}

\author{
Lina Handayani ${ }^{1}$, Azlina Md. Kosnin ${ }^{2}$, Yeo Kee Jiar ${ }^{2}$, Solikhah ${ }^{1}$ \\ 1Universitas Ahmad Dahlan, Faculty of Public Health, Yogyakarta, Indonesia \\ ${ }^{2}$ Universiti Teknologi Malaysia, Faculty of Education, Johor Bahru, Malaysia
}

\begin{abstract}
Abstrak
Latar belakang: Rendahnya rasa percaya diri ibu pasca persalinan berhubungan dengan persepsi tentang kurangnya produksi ASI dan risiko untuk segera berhenti menyusui. WHO/ UNICEF merekomendasikan pemberian ASI eksklusif pada enam bulan pertama setelah kelahiran, kemudian ditambahkan pemberian makanan pendamping ASI secara bertahap sampai usia dus tahun atau lebih. Namun hampir semua negara di dunia belum dapat memenuhi rekomendasi WHO tersebut untuk ASI eksklusif. Meskipun mayoritas ibu awalnya menyusui, namun banyak dari mereka yang terlalu cepat berhenti karena rendahnya rasa percaya diri. Berdasar teori kepercayaan diri, ekspektasi kepercayaan diri dapat mempengaruhi pandangan para ibu terkait kemampuan mereka untuk memulai, mempertahankan dan terus melanjutkan menuyusui.

Metode: Penelitian ini merupakan pilot study

Hasil: Reliabilitas instrumen ini cukup baik dengan nilai Cronbach alfa 0,77, dan 12 item valid, namun ada dua item yang tidak valid.

Kesimpulan: Breastfeeding Self- Efficacy Scale-Short Form (BSES-SF) merupakan instrumen yang sesuai untuk menilai kepercayaan diri dalam hal menyusui para ibu di Indonesia. Proses translasi dan validasi instrumen ini telah dilakukan. Versi bahasa Indonesia dari BSES-SF merupakan instrumen yang cukup valid dan reliabel untuk menilai kepercayaan diri dalam hal menyusui.
\end{abstract}

Kata kunci: percaya diri, ibu, menyusui

\section{Background}

One of the Indonesian health objectives set forth by the Department of Health is that by the year 2010, the proportion of mothers who exclusively breastfeed their infants should increase to $80 \% .{ }^{1}$ Currently the percentage of those who are exclusively breastfeeding is about $32 \%$.

The justification for breastfeeding as the infant feeding method of choice continues to be well documented in the scientific literature. Significant nutritional, anti-allergenic, immunological and psychological benefits of breast milk have been identified. Many studies have described the unique advantages of human milk over artificial formulas. Clinical experiments have established the value of breastfeeding in preventing otitis media, gastroenteritis, asthma, shigella infection, and a variety of other diseases. For the mother, lactation facilitates a faster return to a prepregnant weight while suppressing ovulation for many. The economic advantage and the enhancement of the mother-infant bond have also been discussed as important benefits to breastfeeding. ${ }^{3,4}$ Endorsement for breastfeeding has come from the World Health Organization, the International Pediatric Association, the British Department of Health and Social Security, the American Association of Public Health, and the Academy of Pediatrics. 
The infant feeding decision is complex and involves the influence of psychological, social, and economic factors, and health care system. Several authors have identified education and social support as the key factors in the promotion of breastfeeding. Due to lack of knowledge, sociocultural, economic, and personal reasons, women may choose to bottle-feed completely. Those who do intend to breastfeed may supplement too early with formula, thus undermining the establishment of lactation, or have potentially remediable problems that lead to premature discontinuation of breastfeeding. ${ }^{5}$

Current WHO/ UNICEF recommendations for optimal infant feeding are exclusive breastfeeding for approximately the first 6 months postpartum, after which complementary food should be introduced gradually, with the continuation of breastfeeding until 2 years or beyond. ${ }^{6}$

In the past decade, there has been a myriad of research into the factors affecting breastfeeding duration to identify risk factors for failure. Maternal demographics, attitudes and beliefs, and hospital practices have been examined. ${ }^{7}$ Despite the significant research on the barriers to breastfeeding and the many efforts to promote and support it, almost every country in the world fails to meet the WHO recommendations for exclusive breastfeeding. ${ }^{8}$ For example, in Indonesia the majority of mothers initiate breastfeeding; however, according to WHO only $32 \%$ are exclusively breastfeeding at 6 months. ${ }^{2}$ Among the mothers who do initiate breastfeeding, only $50.12 \%$ are breastfeeding up to 24 months. ${ }^{1}$

Many known predictors of premature breastfeeding discontinuation are nonmodifiable demographic variables such as maternal age, marital status, educational level, and socioeconomic status. ${ }^{7}$ If health professional are to effectively improve low breastfeeding duration rates, they need to reliably asses high-risk women and identify predisposing factors are amenable to intervention. ${ }^{9}$ One possible modifiable variable is breastfeeding confidence.

Higher breastfeeding self efficacy is a complex concept that can change across time. Early breastfeeding experiences following birth have been linked to maternal confidence levels ${ }^{10,11}$ and self-efficacy levels ${ }^{12,13}$, and may influence subsequent intended and actual duration of breastfeeding.

Incorporating self-efficacy theory, developed the breastfeeding self-efficacy concept. ${ }^{14}$ Breastfeeding self-efficacy refers to a mother confidence in her ability to breastfeed her infant. It is an important variable in breastfeeding outcomes as it predicts: (1) whether a mother chooses to breastfeed or not, (2) how much effort she will expend, (3) whether she will have self enhancing or self-defeating thought patterns, and (4) how she will emotionally respond to breastfeeding difficulties. ${ }^{14}$

Breastfeeding self-efficacy is influenced by four main sources of information: (1) performance accomplishments (e.g., past breastfeeding experiences), (2) vicarious experiences (e.g., watching other women breastfeed), (3) verbal persuasion (e.g., encouragement from influential others such as friends, family, and lactation consultants), and (4) physiological responses (e.g., pain, fatigue, stress, anxiety). ${ }^{14,15}$

KES MAS Vol. 7 No. 1, Maret 2013 
2. Method

A. Participant

In this pilot study, there was 18 women from mother who have 0-6 months children in Sewon and Banguntapan, Yogyakarta as the respondents. The data collection was administered by the researcher.

\section{B. Instrument}

The BSES-SF is a 14-item; self-report instrument developed to measure breastfeeding self-efficacy/breastfeeding confidence. All items are preceded by the phrase "I can always" and anchored with a five point scale where one is not all confident and five is always confident. The Cronbach's alpha coefficient for internal consistency of the items is $0.89 .{ }^{16}$

\section{Translation process}

The Breastfeeding Self-Efficacy Scale-Short Form (BSES-SF) is used to collect data related to breastfeeding self-efficacy. ${ }^{7}$ This instrument was translated into Indonesian language by 5 people who are experts in both English and Indonesian language using back translation technique in order to avoid comprehensive errors. Back translation is the process of translating a document that has already been translated into a foreign language back to the original language - preferably by an independent translator.

\section{Result}

In this pilot study, the BSES-SF Indonesian translation version was tested for establishing the reliability and validity of this instrument. Cronbach's alpha is the most common form of internal consistency reliability coefficient. This model internal consistency is based on average correlation among items. Cronbach's alpha of this instrument is 0.77 ; it is meaning the instrument is reliable, because the cut of point level for a good reliability is $0.60 .^{17}$

The validity of this instrument was also tested using analysis with the Pearson correlation $(r)$ with the cut off point is 0.5 . In terms of $r$ values of more than 0.5 , it is mean the item is valid. The result can be seen in the Table 3.1 below:

Table 1: Item validity of the BSES-SF Indonesian translation version

\begin{tabular}{|c|c|c|}
\hline Item & Pearson correlation (r) & Interpretation \\
\hline 1 & 0.864 & Valid \\
\hline 2 & 0.913 & Valid \\
\hline 3 & 0.589 & Valid \\
\hline 4 & 0.796 & Valid \\
\hline 5 & 0.762 & Valid \\
\hline 6 & 0.820 & Valid \\
\hline 7 & 0.199 & Not valid \\
\hline 8 & 0.513 & Valid \\
\hline 9 & 0.724 & Valid \\
\hline 10 & 0.235 & Vot valid \\
\hline 11 & 0.853 & Valid \\
\hline 12 & 0.866 & Valid \\
\hline 13 & 0.744 & Valid \\
\hline 14 & 0.847 & \\
\hline
\end{tabular}


There are two items that not valid, these are item 7 and item 10. It can be happened may be due to the lack of sample numbers. But still, as the whole, the BSES-SF is a suitable instrument fro assessing mothers' breastfeeding confidence among Indonesian mothers.

\section{Limitation of the study} study.

It is a pilot study, so the small number of sample is the most limitation of the

\section{Conclusion}

The BSES-SF Indonesian version is reliable and valid for assessing mothers' breastfeeding confidence.

\section{References}

1. Indonesian Ministry of Health. (2007) Indonesia Health Profile. Center of Data and Information Health Dept.: Jakarta.

2. Statistic Central Bureau. (2007). Indonesia health and demography survey. Health Department: Jakarta.

3. Ball TM, Bennet DM. (2001). The economic impact of breastfeeding. Pediatric Clinic North America, 48(1), 253-62.

4. Labbok M, Perez A, Valdes V. (1994). The lactational amenorrhea method: a new postpartum introductory family planning method with program and policy implication. Adv Contraception, 10, 93-109.

5. Avery, M., Duckett, L., Dodgson, J, K. \& Henly, S.J. (1998). Factors associated with early weaning among primiparas intending to breastfeed. Maternal and Child Health Journal, 2 (3), 167-179.

6. WHO. (2003). The global strategy on infant and young child feeding. A joint WHO/ UNICEF statement. World Health Organization, Geneva, Switzerland.

7. Dennis, C.L., \& Faux, S. (1999). Development and psychometric testing of the breastfeeding self-efficacy scale. Research in Nursing and Health, 22, 399-409.

8. WHO. (2001). World Health Organization. The optimal duration of exclusive breastfeeding. Note for the press no.7. Available at: http://www.who.int/inf-pr2001/en/note2001-07.html.

9. Dennis, C.L. (1999). Theoretical underpinnings of breastfeeding confidence: a self-efficacy framework. Journal of Human Lactation, 15, 195-201.

10. Duckett, L., Henly, S., Avery, M., Potter, S., Hills-Bonczyk, S., Hulden, R. (1998). A theory of planned behavior-based structural model for breastfeeding. Nursing Research, 47(6), 325-336.

11. Piper,S., \& Parks, P.L. (1996). Predicting the duration of lactation: Evidence from a national survey. Birth, 23, 7-12.

12. DiGirolamo, A., Thompson, N., Maryorell, R., Fein, S., \& Grummer Strawn, L. (2005). Intention of experience? Predictors of continued breastfeeding. Health Education and Behavior, 32(2), 208-226.

13. Rothman, A.J. (2000). Toward a theory-based analysis of behavioral maintenance. Health Psychology, 19, 64-69. 
14. Dennis, C.L., Hodnett, E., Gallop, R., \& Chalmers, B. (2002). The effect of peer support on breastfeeding duration among primiparous women: a randomized controlled trial. CMAJ. 166(2), 21-28.

15. Bandura, A. (1977). Self-efficacy: Toward a unifying theory of behavioral change. Psychological Review, 84, 191-215.

16. Wutke, K., Dennis, C.L., (2006). The reliability and validity of the Polish version of the Breastfeeding Self-Efficacy Scale Short Form: Translation and psychometric assessment. International Journal of Nursing Studies, 44, 14391446.

17. Ghozali, I. (2007). Aplikasi analisis multivariate dengan program SPSS. Cetakan ke IV. Badan Penerbit UNDIP: Semarang. 
